\title{
開心術後の手術部位感染発生に関するリスク因子の検討
}

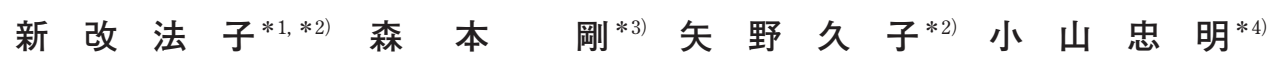

[目的］開心術後に発生する SSI の予防を目的に, SSI バンドルを含めたリスク因子を検討した. [方法] 研 究デザインは後ろ向きコホート研究である. 神戸市立医療センター中央市民病院で 2008 年 1 月 2010 年 12 月（I 期：感染対策実施時期）および新病院移転後の 2014 年 1 月 2016 年 12 月（II 期：感染対策強化時 期）に開心術を施行した 1,579 例を対象にした. SSI のリスク因子は, 単変量解析およびロジスティック回 帰分析を用いて分析した. SSI の判定は米国疾病管理予防センターの医療関連感染調査に使用する SSI 定義 を用いた. [結果] SSI 発生率は 4.5\% であり, I 期と II 期では, SSI 発生率が $6.6 \%$ から $2.9 \%$ に有意に減少 し $(p<0.001)$, 適切な予防抗菌薬の選択, 術後 72 時間以内に予防抗菌薬の中止, 術後 1 日目および 2 日目 朝の血糖管理における対策の実施率が有意に増加していた $(\boldsymbol{p}<0.001)$. 単変量解析の結果, 手術手技, 手術 時期, 手術時間, 術後 2 日目朝血糖值, 切開の 1 時間前以内に予防抗菌薬の投与開始, バンドル $100 \%$ 達成 率において統計学的有意差を認めた. ロジスティック回帰分析の結果, 複合手術 (オッズ比 $2.5 ; 95 \%$ 信頼 区間 1.3 4.8） は SSI の発生する危険性が高くなり, 切開の 1 時間前以内に予防抗菌薬の投与開始（オッズ 比 $0.57 ； 95 \%$ 信頼区間 $0.33 \sim 0.97$ ） と手術時期（II 期，オッズ比 $0.41 ； 95 \%$ 信頼区間 $0.23 \sim 0.71 ）$ はSSI の 発生する危険性が低くなった。 [結語] SSI 予防としては, 特に予防抗菌薬は切開の 1 時間前以内に投与を 開始することが重要であり, SSI バンドルの実施率を向上させること, 複合手術を受ける患者は SSI の発生 に注意を要することが肝要である. 日心外会誌 48 巻 3 号 : 161-169（2019）

$$
\text { キーワード : 開心術 ; 手術部位感染 ; リスク因子 ; SSI バンドル }
$$

\section{Risk Factors for SSI after Open Heart Surgery}

Noriko Shinkai ${ }^{* 1, * 2)}$, Takeshi Morimoto ${ }^{* 3)}$, Hisako Yano ${ }^{* 2)}$ and Tadaaki Koyama*4) (Department of Nursing, Department of Infection Control, Kobe City Medical Center General Hospital*1), Kobe, Japan, Graduate School of Nursing, Nagoya City University*2), Nagoya, Japan, Department of Clinical Epidemiology, Hyogo College of Medicine ${ }^{* 3)}$, Nishinomiya, Japan, Clinical Research Promotion Center, Department of Research Support, Kobe City Medical Center General Hospital*3), Kobe, Japan, and Cardiovascular Surgery, Kobe City Medical Center General Hospital ${ }^{* 4)}$, Kobe, Japan)

Objective : Risk factors for SSI after open heart surgeries were evaluated in relation to a bundle of SSI preventive measures. Methods : Research design is a retrospective cohort study. The study population was 1,579 patients who had received open heart surgeries at Kobe City Medical Center General Hospital from January 2008 to December 2010 (Period I : when standard infection prevention measures were implemented) and from January 2014 to December 2016 (Period II : after a relocation of the hospital to a new campus and enhanced infection prevention measures were implemented). Factors associated with SSI were determined using univariate modelling analysis followed by multi-variate logistic regression analysis. The Center for Disease Control and Prevention definition of SSI was used for case determination. Results : Overall SSI incidence was 4.5\%. SSI incidence decreased significantly from $6.6 \%$ in Period I to $2.9 \%$ in Period II $(p<0.001)$. Significant improvement in adherence to the recommended preventive measures was observed in Period II in selection of appropriate antibiotics, discontinuation of prophylactic antibiotics within $72 \mathrm{~h}$ after surgery and glucose control on post-operative Day 1 and 2 $(p<0.001)$. A univariate analysis showed statistical significance in surgical procedure, surgical period, surgical duration, post-operative day 2 morning glucose level, administration of prophylactic antibiotics

\footnotetext{
本論文の一部は, 第 48 回日本心臟血管外科学会 $(2018$ 年, 三重) において発表した。 2018 年 8 月 31 日受付, 2019 年 1 月 9 日採用 Corresponding author : Noriko Shinkai Department of Nursing, Department of Infection Control, Kobe City Medical Center General Hospital, Kobe, Japan

*1) 神戸市立医療センター中央市民病院 看護部感染管理 室 $\left.{ }^{* 3}\right)$ 同 臨床研究推進センター学術・研究支援部門; 兵 庫医科大学臨床疫学 *4) 同 心臟血管外科 干 651-0054 神戸市中央区港島南町 2-1-1

*2) 名古屋市立大学大学院看護学研究科
}

本研究に打いて一切の利益相反や研究資金の提供はない. None of the authors of this manuscript has any financial or personal relationship with other people or organizations that could inappropriately influence their work. 
within $1 \mathrm{~h}$ before incision, $100 \%$ compliance with the Bundle. Complex surgery (odds ratio $2.5 ; 95 \% \mathrm{CI}$ $1.3 \sim 4.8$ ) were identified as a risk factor by multiple logistic regression. Surgical period (Period II, odds ratio $0.41 ; 95 \% \mathrm{CI} 0.28 \sim 30.71)$ and administration of prophylactic antibiotics within $1 \mathrm{~h}$ before incision (odds ratio $0.57 ; 95 \% \mathrm{CI} 0.33 \sim 0.97$ ) reduced SSI risks. Conclusion : The study demonstrated administration of prophylactic antibiotics within $1 \mathrm{~h}$ before incision was particularly important for SSI prevention. Higher compliance with SSI bundle and a special attention to patients receiving complex surgery were also warranted. Jpn. J. Cardiovasc. Surg. 48:161-169 (2019)

Keywords : open heart surgery ; surgical site infection ; risk factor ; SSI bundle

\section{はじめに}

手術部位感染（Surgical site infection, 以下 SSI）は, 手

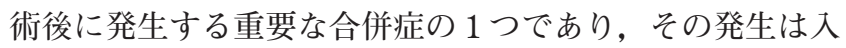
院期間の延長や医療コストの増大, 患者の満足度低下など 患者と医療機関の双方に多くの不利益を生じる ${ }^{1)}$.

厚生労働省院内感染サーベイランス事業（Japan Nosocomial Infections Surveillance, 以下 JANIS）の報告 ${ }^{2}$ によ ると，SSI 発生率は，0～ $25.3 \%$ と手術手技によって異な り, 食道手術や肝胆膵手術が $19.4 \sim 25.3 \%$ と高い傾向に あった。 心臟血管外科手術は $2.1 \sim 4.1 \% て ゙ あ り$, 消化器外 科手術に比べると低い傾向にあるが，同じ清潔手術に分類 される整形外科手術では $0.6 \sim 1.9 \%$, 開頭術は $1.7 \%$ であ り，心臟血管外科手術後 SSI 発生率は高い傾向にあった。 さらに, 長時間手術や体外循環の使用, 多数のカテーテル やドレーン留置, 人工物の体内埋め込みといった手術の特 徵から, 術後に SSI が発生するリスクは高い。ひとたび感 染症を発生すれば縦隔洞炎のような重篤な合併症に繋が

り, 死亡率は $12 \sim 50 \%$ ときわめて高い ${ }^{3)}$.

心臟血管外科手術後のSSI 発生に打けるリスク因子の報 告には, 糖尿病 ${ }^{3 \sim 5}$, 肥満 ${ }^{3,4)}$, 手術時間 ${ }^{3)}$, 高齢, 輸血 ${ }^{4{ }^{4}}$ な ぞ患者や手術に関連した要因がある，米国では，SSIを含 む術後合併症削減を目的に，エビデンスレベルの高い予防 策をバンドルとしてまとめて実施する Surgical care improvement project $(\mathrm{SCIP})^{6)}$ が実施され，SCIP の SSI 予防 効果について検討したシステマティックレビューでは SSI の減少に寄与する報告がある7)。神戸市立医療センター中 央市民病院 (以下, 当院) では, 2008 年から SSI 対策に 取り組み, 2011 年 7 月に新病院移転後も新たな対策を取 り入れながら SSI 対策を継続してきた. 今回，開心術後の SSI 予防を目的に, 当院で開心術を施行した患者を対象 に，SSIバンドルを含むSSIリスク因子を検討した。

\section{方法}

\section{1. 対 象}

2008 年 1 月〜 2010 年 12 月および 2014 年 1 月〜 2016 年 12 月までに当院で開心術（左開胸を含む）を施行した患
者を対象とした。術式はJANIS の手術手技コードを参考 に 4 つに分類した. すなわち, 弁膜症, 先天性などの心臓 手術 (cardiac surgery, 以下 CARD), 胸部とグラフト採 取部位の切開（胸部のみの切開含む）を伴う冠動脈バイパ 又術 (coronary artery bypass graft, 以下 $\mathrm{CABG}$ ), 胸部大 動脈の手術 (thoracic aortic aneurysm, 以下 TAA), そし て CARD， CABG，TAAのうち，2 手術手技以上を施行し た場合を複合手術とした。 20 歳未満の症例，追跡期間中 にSSI 以外の要因で死亡した症例打よび開胸状態のまま手 術室を退室した症例は除外した。当院は 2011 年 7 月に新 病院に移転し，移転後から感染対策を継続強化した. 2014 年から SSI サーベイランスを再開したため, 移転前の旧病 院で感染対策を開始した 2008 年 1 月〜 2010 年 12 月を I 期，新病院移転後のサーベイランスを再開した 2014 年 1 月〜2016 年 12 月を II 期として手術時期を分類し比較し た.

\section{2. 当院の SSI 予防策}

I 期の旧病院では, 2008 年から手術部位のカミソリ剃毛 を廃止し, クリッパーによる除毛に変更した。術前には患 者の歯科診と口腔ケアを実施し，術前日に非抗菌石喃によ るシャワー浴を施行した。術野を消毒する前に $76.9 \sim 81.4$ vol $\%$ エタノールで皮脂を拭き取り, 皮膚切開の 1 時間前 からセファゾリン等の予防抗菌薬投与を開始した。患者の 体温管理では, 手術操作に必要な場合を除き, 低体温を予 防した。術者や器械出し看護師は, スクラビング法による 手術時手洗いを導入した. 2009 年は新たにメチシリン耐 性黄色ブドゥ球菌（methicillin-resistant Staphylococcus aureus, 以下 MRSA）の鼻腔スクリーニングと陽性者の除菌, 術後血糖管理 (<160 mg/dl を目標), ドレーンの早期抜 去を行い, 手術チームと感染管理室（infection control team，以下 ICT) の協働により予防抗菌薬プロトコール (セファゾリン $1 \sim 2 \mathrm{~g}$ を切開 1 時間前以内と術中 3 時間ご と, 術後 72 日以内で終了, MRSA 陽性者は術中抗菌薬を バンコマイシン $1 \mathrm{~g}$ ，緊急手術はセファゾリンとバンコマ イシンを併用投与）を実践した。

II 期の新病院では, これまでの対策を継続し, 術中 3 時 間ごとの手袋交換や，術者の耳と毛髪を覆う頭巾の着用， 
ICT と外科医による創部回診, 単回使用沉用サージカルド レープ (インテグシール) 塗布の対策を追加した。

\section{3. 研究デザインとデータ収集}

研究デザインは, 後ろ向きコホート研究である. SSI の リスクと考えられる情報 ${ }^{3,4,8)}$, SCIP の SSI バンドル情報6) およびSSI 診断情報 ${ }^{8}$ を診療録と電子カルテから収集し た。年齢, 性別, 肥満度 (Body Mass Index, 以下 BMI), 哭煙, 糖尿病, 高血圧, 脂質異常症, 透析, 開胸歴, 術前 HbA1c, 術前左室駆出率, アメリカ麻酔科医学会 (American Society of Anesthesiologists，以下ASA） スコア，手術 創の污染度, 除毛方法, 手術手技, 手術時期, 緊急度, 再 開胸，手術時間，体外循環使用の有無と時間，大動脈遮断 の有無と時間, 出血量, 自己血回収（セルセーバー）によ る返血の有無, 退室時中枢温, 周術期抗菌薬投与, 術後 1 日目朝および 2 日目朝血糖值, SSI の有無, 感染部位であ る。哭煙は過去に一度でも喫煙歴のあった症例，糖尿病， 高血圧, 脂質異常症は疾患の有無とし, 透析は手術時に血 液または腹膜透析を実施していた症例，開胸歴は過去に開 心術を 1 度以上経験した症例とした。手術時間は皮膚を切 開して閉鎖までの時間とし，術後 24 時間以内に同じ切開 創を通じて手術操作が行われた場合はその合計時間とし た。

SSI バンドルの内容は，1）切開の 1 時間前以内に予防 抗菌薬の投与を開始，2）適切な予防抗菌薬（セファゾリ ンまたはバンコマイシン）を選択，3）術後 72 時間以内に 予防抗菌薬を中止，4）術後 1 日目朝の血糖值を $160 \mathrm{mg} /$ $\mathrm{dl}$ 未満にコントロール，5）術後 2 日目朝の血糖值を 160 $\mathrm{mg} / \mathrm{dl}$ 未満にコントロール，6）体温管理（手術終了後の
体温 36 度以上に維持)，7）剃刀廃止とクリッパーによる 除毛, 以上 7 項目である.

本研究は名古屋市立大学看護学部研究倫理審査 (ID : 16015）扎よび当院の臨床研究倫理委員会（審査 No： zh180613）の承認を得た。

\section{SSI の定義と追跡期間}

SSI は米国疾病管理予防センター (Centers for Disease Control and Prevention, 以下 CDC) の定義量老用い, 表層 切開創感染, 深部切開創感染, 臓器/体染感染のすべてを 合わせて SSI とした. 判定は研究者である感染症看護専門 看護師と心臓血管外科医が行った. SSI の追跡期間は入院 中とし, 退院後にSSI を発症して外来受診や入院した場合 で，人工物を留置している場合は 1 年，それ以外は 30 日 以内にSSI を発症した場合を含めた。

\section{5. 解析方法}

記述統計を行った後, SSI バンドルの実施率を手術時期 で比較した。次に, SSI群と非 SSI 群において単変量解析 を行った。連続変数の場合は, $t$ 検定またはWilcoxon 検 定, 順序变数の場合は $\chi^{2}$ 検定または Fisher 正確確率検定 を行った。

この結果に基づいて, 多重ロジスティック回帰分析によ る多变量解析を行った。手術時間 (5 時間以上/未満), 手 術時期 (I 期/II 期), 手術手技, SSI ケアバンドル, 年齢 (65 歳以上/未満), 性別でリスク調整した. SSI バンドル のうち, 実施率が 100\%に近い対策は関連要因から除外す るものとした。統計解析にはJMP 13.0 を使用した。

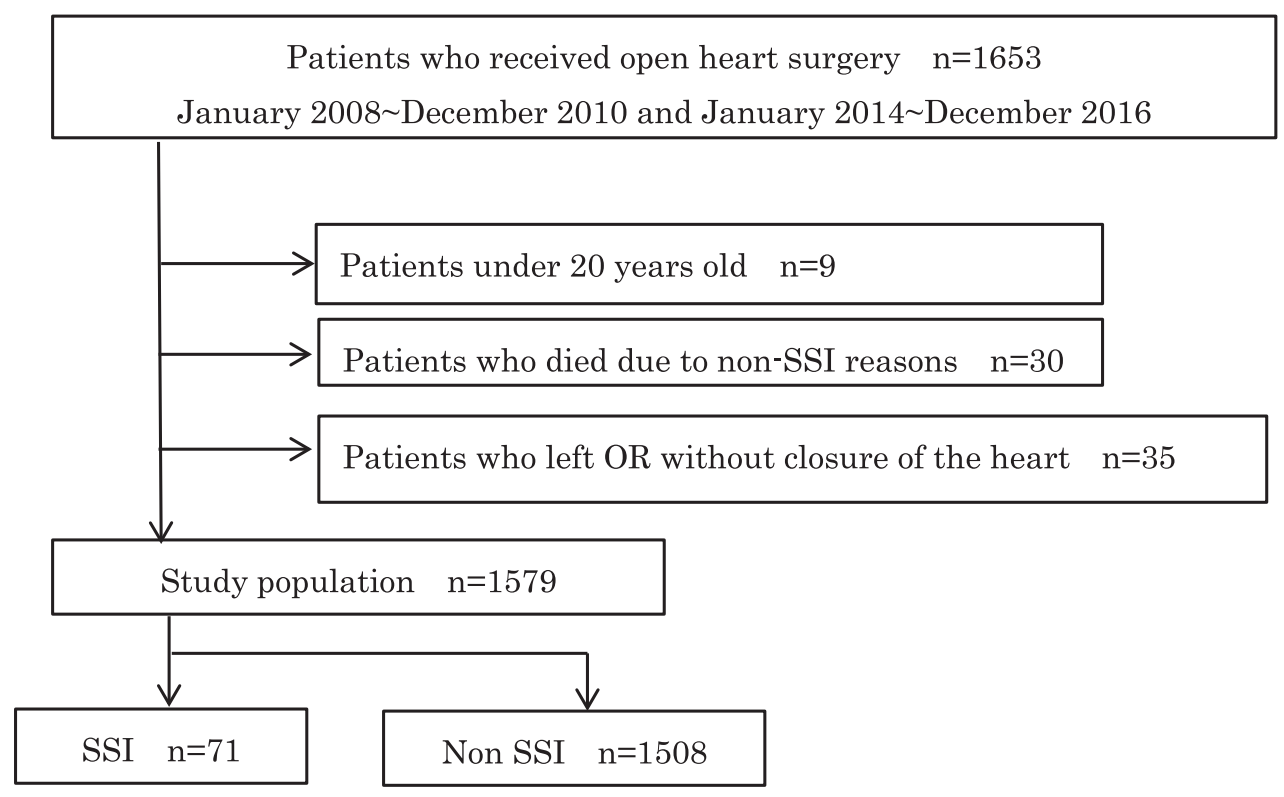

Fig. 1 Flowchart of included patients $\mathrm{OR}$, operation room; SSI, surgical site infection. 
Table 1 Characteristics of subjects

\begin{tabular}{|c|c|}
\hline Variables & Subjects $(n=1,579)$ \\
\hline Age, mean $\pm \mathrm{SD}$ & $68 \pm 12$ \\
\hline $20-59, n \quad(\%)$ & $328(21)$ \\
\hline $60-69, n \quad(\%)$ & $422(27)$ \\
\hline $70-79, n \quad(\%)$ & $607(38)$ \\
\hline$\geqq 80, n \quad(\%)$ & $222(14)$ \\
\hline Men, $n$ (\%) & $971(61)$ \\
\hline BMI $\left(\mathrm{kg} / \mathrm{m}^{2}\right)$, mean $\pm \mathrm{SD}$ & $23 \pm 3.6$ \\
\hline \multicolumn{2}{|l|}{ Preoperative factor, $n$} \\
\hline Smoking & $792(50)$ \\
\hline Diabetes & $418(26)$ \\
\hline Hypertension & $907 \quad(57)$ \\
\hline Hyperlipidemia & $361 \quad(23)$ \\
\hline Dialysis history & $93(5.9)$ \\
\hline History of open heart surgery & $197(12)$ \\
\hline ASA score $\geqq 3$ & $1,240 \quad(78)$ \\
\hline Wound class (contaminated/dirty) & $64(4.1)$ \\
\hline HbA1c $(\%)$, mean \pm SD & $5.9 \pm 0.9$ \\
\hline $\mathrm{LVEF}(\%)$, mean $\pm \mathrm{SD}$ & $58 \pm 12$ \\
\hline \multicolumn{2}{|l|}{ Intraoperative/Postoperative factor } \\
\hline \multicolumn{2}{|l|}{ Surgical procedure, $n$ (\%) } \\
\hline CADR & $700(44)$ \\
\hline CABG & $384(24)$ \\
\hline TAA & $218(14)$ \\
\hline Complex surgery & $277(18)$ \\
\hline Surgical period (Period II), $n$ (\%) & $916 \quad(58)$ \\
\hline Emergency operation, $n$ (\%) & $281(18)$ \\
\hline Re-open heart surgery, $n$ (\%) & $35(2.2)$ \\
\hline Operative duration (min), median (IQR) & $377(308-455)$ \\
\hline Duration of pump, $n$ (\%) & $1,350(85)$ \\
\hline Duration of pump oxygenator (min), median (IQR) & $175(132-220)$ \\
\hline Aortic clamping, $n$ (\%) & $756(48)$ \\
\hline Duration of aortic clamping (min), median (IQR) & $116(83-152)$ \\
\hline Intra-operative bleeding (ml), median (IQR) & $486(309-802)$ \\
\hline Intra-operative return of autologous blood, $n$ (\%) & $1,526(97)$ \\
\hline Core temperature when leaving $\mathrm{OR}$, mean $\pm \mathrm{SD}$ & $36.6 \pm 0.8$ \\
\hline \multicolumn{2}{|l|}{ Post-operative glucose level $(\mathrm{mg} / \mathrm{dl})$, mean $\pm \mathrm{SD}$} \\
\hline Day 1 morning & $144 \pm 26$ \\
\hline Day 2 morning & $140 \pm 31$ \\
\hline
\end{tabular}

$\mathrm{SD}$, standard deviation ; IQR, interquartile range ; BMI, body mass index ; LVEF, left ventricular ejection fraction; ASA, American Society of Anesthesiologists ; CARD, cardiac surgery; $\mathrm{CABG}$, coronary artery bypass graft; TAA, thoracic aortic aneurysm ; OR, operation room.

\section{結果}

\section{1. 対象者の特徵（Fig. 1, Table 1)}

対象患者を示す。全体で 1,579 例であり，平均年齢 68土12 歳, 男性 61\%（971例）であった。術式は, CARD 44\% (700 例), CABG 24\% (384 例), TAA 14\% (218 例), 複合手術 $18 \%$ (277 例) であり, CARD が約半数を占めて いた。

\section{SSI 発生率と SSI ケアバンドルの評価（Table 2)}

SSI 発生率は 4.5\% (71 例) であり, 表層切開創感染 1.1\% (18 例), 深部切開創感染 $0.7 \%$ (11 例), 臓器/体腔感
染 2.7\%（42 例）であった。I 期と II 期の SSI 発生率は，I 期 6.6\%, II 期 2.9\% であり, II 期において有意に減少し $(p<0.001)$, 感染部位別発生率は臟器/体腔感染が有意に 減少した $(p=0.01)$.

SSI バンドル実施率は, 適切な予防抗菌薬の選択, 術後 72 時間以内に抗菌薬投与を終了, 術後 1 日目朝および 2 日目朝血糖值（<160 mg/dl）の対策が II 期で有意に増加 していた $(p<0.001)$ 。バンドル $100 \%$ 達成率は全体で $38 \%$ であり，I 期 27\% から II 期 45\% に有意な増加を認めた $(p<0.001)$. 
Table 2 Comparison of SSI incidence and SSI bundle implementation rate by surgical period

\begin{tabular}{|c|c|c|c|c|}
\hline & $\begin{array}{c}\text { Total } \\
(n=1,579)\end{array}$ & $\begin{array}{c}\text { Period I ; } \\
2008-2010 \\
(n=663)\end{array}$ & $\begin{array}{c}\text { Period II ; } \\
2014-2016 \\
(n=916)\end{array}$ & $p$-Value \\
\hline Incidence of SSI, $n$ (\%) & $71(4.5)$ & $44(6.6)$ & $27(2.9)$ & $<0.001$ \\
\hline Superficial incisional SSI & $18(1.1)$ & $8(1.2)$ & $10(1.1)$ & 0.01 \\
\hline Deep incisional SSI & $11(0.7)$ & $4(0.6)$ & $7(0.8)$ & \\
\hline Organ/space SSI & $42(2.7)$ & $32(4.8)$ & $10(1.1)$ & \\
\hline \multicolumn{5}{|l|}{ SSI bundle, $n$ (\%) } \\
\hline Administration of prophylactic antibiotics within $1 \mathrm{~h}$ of incision & $1,236(78)$ & $501(76)$ & $735(80)$ & 0.026 \\
\hline Appropriate antibiotic selection & $1,565(99)$ & $650(98.0)$ & $915(99.9)$ & $<0.001$ \\
\hline Discontinuation of antibiotics within $72 \mathrm{~h}$ after surgery & $1,268(83)$ & $442(69)$ & $826(93)$ & $<0.001$ \\
\hline Post-operative day 1 morning glucose level $<160 \mathrm{mg} / \mathrm{dl}$ & $1,231(78)$ & $485(73)$ & $746(82)$ & $<0.001$ \\
\hline Post-operative day 2 morning glucose level $<160 \mathrm{mg} / \mathrm{dl}$ & $1,245(79)$ & $473(71)$ & $772(85)$ & $<0.001$ \\
\hline Core temperature when leaving $\mathrm{OR} \geqq 36^{\circ} \mathrm{C}$ & $1,379(87)$ & $579(87)$ & $800(87)$ & 1.0 \\
\hline Using clippers for surgical site hair removal & $1,579(100)$ & $663(100)$ & $916(100)$ & - \\
\hline $100 \%$ compliance with the bundle, $n(\%)$ & $582(38)$ & $179(27)$ & $412(45)$ & $<0.001$ \\
\hline
\end{tabular}

SSI, surgical site infection; OR, operation room.

Table 3 Comparison of SSI bundle implementation rate by infection site

\begin{tabular}{|c|c|c|c|c|}
\hline Variable & $\begin{array}{c}\text { Organ/space SSI } \\
(n=42)\end{array}$ & $\begin{array}{c}\text { Superficial/ } \\
\text { Deep incisional SSI } \\
(n=29)\end{array}$ & $\begin{array}{l}\text { Non SSI } \\
(n=1,508)\end{array}$ & $p$-Value \\
\hline \multicolumn{5}{|l|}{ SSI bundle, $n$ (\%) } \\
\hline Administration of prophylactic antibiotics within $1 \mathrm{~h}$ of incision & $28(67)$ & $18(62)$ & $1,190(79)$ & 0.017 \\
\hline Appropriate antibiotic selection & $42(100)$ & $29(100)$ & $1,494(99)$ & 0.72 \\
\hline Discontinuation of antibiotics within $72 \mathrm{~h}$ after surgery & $30(73)$ & $22(81)$ & $1,216(83)$ & 0.24 \\
\hline Post-operative day 1 morning glucose level $<160 \mathrm{mg} / \mathrm{dl}$ & $26(62)$ & $24(83)$ & $1,181(78)$ & 0.033 \\
\hline Post-operative day 2 morning glucose level $<160 \mathrm{mg} / \mathrm{dl}$ & $26(62)$ & $22(76)$ & $1,197(80)$ & 0.017 \\
\hline Core temperature when leaving $\mathrm{OR} \geqq 36^{\circ} \mathrm{C}$ & $33(79)$ & $24(83)$ & $1,322(88)$ & 0.16 \\
\hline Using clippers for surgical site hair removal & $42(100)$ & $29(100)$ & $1,508(100)$ & - \\
\hline
\end{tabular}

SSI, surgical site infection.

\section{3. 手術時期別感染部位別 SSI ケアバンドルの評価}

(Table 3)

I 期/II 期において, 臓器/体腔感染が有意に減少したた め, 臓器/体腔感染, 表層・深部感染, 感染なしの 3 つの 群に分類し，SSI ケアバンドル実施率を調査した。その結 果, 切開の 1 時間前以内の予防抗菌薬投与開始, 術後 1 日 目および 2 日目朝血糖值（<160 mg/dl）の対策において 有意差を認めた。

\section{4. リスク因子の単変量解析 (Table 4)}

単変量解析の結果, 手術手技; CADR, 手術手技; 複合 手術，手術時期，手術時間，切開の 1 時間前以内の予防抗 菌薬投与開始, 術後 2 日目朝血糖值, バンドル $100 \%$ 達成 率において統計学的有意差を認めた。

\section{5. ロジスティック回帰分析による多変量解析}

(Table 5)

複合手術（オッズ比 $2.5 ， 95 \% \mathrm{CI} 1.3$ 4.8） が SSI を発 生する危険性が高くなり, 切開の 1 時間前以内に予防抗菌 薬の投与開始（オッズ比 $0.57,95 \% \mathrm{CI} 0.33 \sim 0.97$ ） と, 手 術時期（II 期，オッズ比 0.41 ，95\%CI $0.23 〜 0.71 ）$ はSSI
を発生する危険性が低下した。

\section{考察}

心臓血管外科の開心術を受けた 1,579 例のデータを解析 し, 患者要因, 手術要因, 感染対策要因からリスク因子を 検討した。その結果，複合手術はSSIを発生する危険性が 高くなり，切開の 1 時間前以内の予防抗菌薬投与開始と手 術時期が II 期においてはSSI の発生する危険性が低く なった。

本研究では, CARD, CABG, TAAのいずれか 2 手術手 技以上の術式を複合手術と定義して解析した。その結果, 複合手術が SSI の発生するリスクが高いことが明らかと なった。複合手術の患者は，手術時間が延長することが推 測される。今回の解析では, 手術時間 (5 時間) で補正し た結果リスク因子にはあがらなかったが，オッズ比 2.2 倍 であり，長時間手術はSSIにつながるリスク要因と考えら れた。長手術時間がSSIのリスク因子であることはすでに 報告され3)，以前にわれわれが実施した調査に扎いても手 術時間がリスク因子であった ${ }^{9)}$ 。また長時間手術のみなら 
Table 4 Univariate analysis of variables associated with SSI

\begin{tabular}{|c|c|c|c|}
\hline Variable & SSI $(n=71)$ & Non SSI $(n=1,508)$ & $p$-Value \\
\hline Age $\geqq 65$ years, $n \quad(\%)$ & $45(63)$ & $1,032(68)$ & 0.37 \\
\hline Men, $n \quad(\%)$ & $49(69)$ & $922(61)$ & 0.18 \\
\hline $\mathrm{BMI} \geqq 25 \mathrm{~kg} / \mathrm{m}^{2}, n$ & $23(32)$ & $341 \quad(23)$ & 0.058 \\
\hline \multicolumn{4}{|l|}{ Preoperative factor, $n$ (\%) } \\
\hline Smoking & $41(58)$ & $751(50)$ & 0.19 \\
\hline Diabetes & $13(18)$ & $405(27)$ & 0.11 \\
\hline Hypertension & $44 \quad(62)$ & $863(57)$ & 0.43 \\
\hline Hyperlipidemia & $19(27)$ & $342(23)$ & 0.42 \\
\hline Dialysis history & $7(10)$ & $86(6)$ & 0.19 \\
\hline History of open heart surgery & $14(20)$ & $183(12)$ & 0.059 \\
\hline ASA score $\geqq 3$ & $57(80)$ & $1,183(78)$ & 0.71 \\
\hline Wound class (contaminated/dirty) & $5(8)$ & $59(4)$ & 0.19 \\
\hline $\mathrm{HbA} 1 \mathrm{c} \geqq 6.5 \quad(\%)$ & $12(18)$ & $267(19)$ & 0.72 \\
\hline $\mathrm{LVEF} \leqq 55 \quad(\%)$ & $20(29)$ & $390(28)$ & 0.77 \\
\hline \multicolumn{3}{|l|}{ Intraoperative/ Postoperative factor, $n$ (\%) } & Surgical procedure \\
\hline CARD & $22(31)$ & $678(45)$ & 0.021 \\
\hline $\mathrm{CABG}$ & $17(24)$ & $367(24)$ & 0.94 \\
\hline TAA & $10(14)$ & $208(14)$ & 0.94 \\
\hline Complex surgery & $22(31)$ & $255(17)$ & 0.0023 \\
\hline Surgical period (Period II) & $27(38)$ & $889(59)$ & $<0.001$ \\
\hline Emergency surgery & $10(14)$ & $271(18)$ & 0.40 \\
\hline Re-open heart surgery & $4(5.6)$ & $31(2.1)$ & 0.069 \\
\hline Operative duration $\geqq 5 \mathrm{~h}$ & $65(92)$ & $1,165(74)$ & 0.0052 \\
\hline Duration of pump & $64(90)$ & $1,286(85)$ & 0.26 \\
\hline Aortic clamping & $40(56)$ & $716(47)$ & 0.14 \\
\hline Intra-operative bleeding $\geqq 486 \quad(\mathrm{ml})$ & $43(61)$ & $747(50)$ & 0.069 \\
\hline $\begin{array}{l}\text { Intra-operative return of autologous blood } \\
\text { glucose level }(\mathrm{mg} / \mathrm{dl}) \text {, mean } \pm \mathrm{SD}\end{array}$ & $69(97)$ & $1,457 \quad(97)$ & 0.80 \\
\hline Post-operative day 1 morning & $149 \pm 31$ & $144 \pm 26$ & 0.065 \\
\hline Post-operative day 2 morning & $147 \pm 35$ & $140 \pm 31$ & 0.042 \\
\hline \multicolumn{4}{|l|}{ SSI bundle, $n$ (\%) } \\
\hline Administration of prophylactic antibiotics within $1 \mathrm{~h}$ of incision & $46(65)$ & $1,190(79)$ & 0.0048 \\
\hline Appropriate antibiotic selection & $71(100)$ & $1,494(99)$ & 1.0 \\
\hline Discontinuation of antibiotics within $72 \mathrm{~h}$ after surgery & $52(76)$ & $1,216(83)$ & 0.15 \\
\hline Post-operative day 1 morning glucose level $<160 \mathrm{mg} / \mathrm{dl}$ & $50(70)$ & $1,181(78)$ & 0.11 \\
\hline Post-operative day 1 morning glucose level $<160 \mathrm{mg} / \mathrm{dl}$ & $48(68)$ & $1,197(80)$ & 0.014 \\
\hline Core temperature when leaving $\mathrm{OR} \geqq 36\left({ }^{\circ} \mathrm{C}\right)$ & $57(80)$ & $1,322(83)$ & 0.068 \\
\hline Using clippers for surgical site hair removal & $71(100)$ & $1,508(100)$ & - \\
\hline $100 \%$ compliance with the bundle, $n(\%)$ & $15(21)$ & $576(38)$ & 0.0037 \\
\hline
\end{tabular}

SD, standard deviation; SSI, surgical site infection ; BMI, body mass index; LVEF, left ventricular ejection fraction ; ASA, American Society of Anesthesiologists; CARD, cardiac surgery; CABG, coronary artery bypass graft; TAA, thoracic aortic aneurysm; OR, operation room.

ず，体外循環時間や出血量，輸血もSSI 影響している可 能性はある。今回，輸血の調査はできていないが，これら のデータは互いに相関することが推測され, 実際に本研究 の手術時間と体外循環時間や出血量の相関関係を確認した ところ，相関が高い傾向にあった。サンプル数の問題およ び相関のある因子は解析から除外したため, 手術時間（5 時間）のみを補正因子に加えた結果であるが，手術時間に 加えて体外循環時間, 出血量, 輸血もリスクにつながる可 能性があることは念頭におく必要がある.

さらに，複合手術の患者は複数の疾患を有していること
から，術前状態が SSI につながることが推測される，今回 の結果では, 術前の全身状態を示すASA スコアや手術創 分類はSSI 発生に対する有意差を認めなかったためSSI へ の影響は少ないと考えられたが，対象患者の $78 \%$ が ASA スコア 3 以上であったことや, 術前感染創の症例が $4 \%$ と 少なかったため有意差に反映しなかった可能性はある. Lemaignen らの報告 ${ }^{4)}$ では術前状態が SSI のリスク因子で あり，今回調査はできていないが，心不全の既往や慢性閉 塞性肺疾患 (chronic obstructive pulmonary disease, 以下 COPD）もリスク因子として報告されている ${ }^{10)}$. 
Table 5 Logistic regression analysis of variables associated with SSI

\begin{tabular}{lccc}
\hline \multicolumn{1}{c}{ Variable } & Odds ratio & $95 \% \mathrm{CI}$ & $p$-Value \\
\hline Age $\geqq 65$ years old & 0.78 & $0.46-1.3$ & 0.36 \\
Men & 1.3 & $0.72-2.2$ & 0.43 \\
Operative duration $\geqq 5 \mathrm{~h}$ & 2.2 & $0.85-5.8$ & 0.102 \\
Surgical period (Period II) & 0.41 & $0.23-0.71$ & 0.0017 \\
Surgical procedure & & & - \\
CARD & reference & - & 0.77 \\
CABG & 1.1 & $0.54-2.3$ & 0.38 \\
TAA & 1.5 & $0.63-3.4$ & 0.0071 \\
Complex surgery & 2.5 & $1.3-4.8$ & \\
Bundle & & & 0.040 \\
Administration of prophylactic antibiotics within $1 \mathrm{~h}$ of incision & 0.57 & $0.33-0.97$ & 0.91 \\
Discontinuation of antibiotics within $72 \mathrm{~h}$ after surgery & 1.03 & $0.56-1.9$ & 0.34 \\
Post-operative day 1 morning glucose level $<160 \mathrm{mg} / \mathrm{dl}$ & 0.77 & $0.44-1.3$ & 0.30 \\
Post-operative day 1 morning glucose level $<160 \mathrm{mg} / \mathrm{dl}$ & 0.74 & $0.42-1.3$ & 0.14 \\
Core temperature when leaving OR $\geqq 36 \mathrm{C}$ & 0.6 & $0.32-1.2$ & \\
\hline
\end{tabular}

CI, confidence interval; CARD, cardiac surgery ; CABG, coronary artery bypass graft; TAA, thoracic aortic aneurysm.

以上より，複合手術を受ける患者はSSI の発生を注意深 く観察していくとともに，更なる解析を深めることで刘策 を検討していくことが必要である.

次に，今回の調查では，SSI バンドルの構成要素であ る，切開の 1 時間前以内に予防抗菌薬の投与開始が SSI の リスクを下げる因子として明らかになった。予防抗菌薬投 与の目的は SSI 発生の減少であり，薬剤の選択，投与の夕 イミング，投与量，そして投与期間を考慮することが重要 である ${ }^{8,11}$. 投与のタイミングについては，手術が始まる 時点で十分な殺菌作用を占める血中濃度，組織濃度が必要 であり，切開の 1 時間前以内に投与を開始することが推奨 されている ${ }^{8,11)}$. 本研究では, 切開の 1 時間前以内の投与 開始に打ける実施率は全体で $80 \%$ であり，20\% は切開の 1 時間前を超えていた，当院では，患者が手術室に入室し， 末梢静脈カテーテルを留置した直後に抗菌薬の投与を開始 している．開心術の特徴として，手術開始までに複数の血 管カテーテルの留置や経食道エコーによる術前の所見確 認，手術の体位固定や皮膚消毒といった複数の処置があ り，手術開始までに時間を要することが多い．投与開始か ら切開までに 1 時間を超えることがあるため，その結果投 与のタイミングが早かったものと考えた。現在は，投与の タイミングを手術チームと相談し，スワンガンツカテーテ ルを留置した後に同カテーテルから投与する手順を定め た.

今回，手術時期を I 期と II 期に分類し解析した結果， 手術時期が II 期において SSI の発生するリスクが低いこ とが分かった。当院は 2011 年 7 月に新築移転しており, 環境の変化に伴う複数の要因が SSI の減少に寄与した可能 性が考えられる，手術室の環境が大きく変わり，清潔度の 違いによる影響の可能性があること，近年の医療技術の高
度化に伴う低侵襲手術や体外循環を使用しない手術の増加 といった時代の変化がある. 医療者の入れ替わりにより， 新たな感染対策も実施され，こういった要因が SSI の減少 につながっていると考える.

一方で感染対策の視点から分析したところ，II 期では適 切な予防抗菌薬の選択, 術後 72 時間以内に予防抗菌薬の 投与中止，術後 1 日目および 2 日目朝血糖管理（<160 $\mathrm{mg} / \mathrm{dl}$ ) の実施率が有意に上昇し，バンドル $100 \%$ 達成率 は I 期 27\% から II 期 45\% に有意に増加した。SSI 発生率は I 期 6.6\%から II 期 2.9\% に有意に減少しており，バンドル 実施率の向上はSSI の発生予防に寄与したと考える. バン ドルとは，エビデンスレベルが高い複数の予防策を同時に まとめて実践することで，感染予防につながりやすい ${ }^{12)}$ して, 米国 ${ }^{13)}$ や英国 ${ }^{14)}$ からケアバンドルの実施が提唱され ている. 米国ではこのバンドルを取り入れ，SSIを含めた 術後合併症の削減を目的とした Surgical care improvement project（SCIP）が実施され ${ }^{6)}$, SSI の減少に寄与する報 告》がある. バンドルの効果においては，以前報告してい るが ${ }^{15)}$, 今回も同様の結果が確認された。ケアバンドルの 遵守率を上げることは重要なことと考える.

I 期/II 期の感染率の比較において, 臓器/体腔感染の有 意な減少を認めた。そこでバンドル実施率を感染部位別に 分析したところ，切開の 1 時間前以内の予防抗菌薬投与開 始と術後 1 日目および 2 日目朝血糖值に有意差を認めた。 術後血糖管理については, 術後 3 日間の血糖值を $80 \sim 150$ $\mathrm{mg} / \mathrm{dl}$ に厳格管理した結果，深部創感染が $2.6 \%$ から $1.0 \%$ に有意に減少した Kramer らの報告 ${ }^{16)}$ と一致し, 近年発表 された複数のガイドライン ${ }^{17,18)}$ でも推奨されている. 本結 果から, 血糖管理は特に臟器/体腔 SSI 予防の重要な対策 の 1 つと考えられたが, SSI の発生日や起因菌などを含め 
て検討する余地がある。

心臓血管外科手術後のリスク因子に関する先行研究で は, 糖尿病, 高齢者, 喫煙, 肥満, 開胸歴, 心不全, COPD, 手術時間などの患者打よび手術操作に関連した要 因が報告されていた ${ }^{3 \sim 5,10)}$. 本研究は, 全開心術を対象と

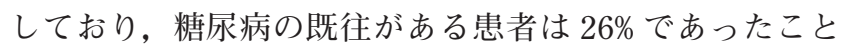
がリスク因子に抽出されなかった要因の 1 つと考える.ま た, 対象者の平均年齢は 68 歳であり, 70 歳以上の高齢者 が $52 \%$ を占めていた。手術患者の多くが高齢であったこ とから，年齢による有意差を認めなかったと考える．肥満 患者は創感染を発生しやすく ${ }^{19)}$, 原因として過度な率引に よる組織損傷や死腔の不完全な閉鎖などがあげられてい る. 本研究でも単変量解析の結果, BMI $25 \mathrm{~kg} / \mathrm{m}^{2}$ 未満に 比較して $25 \mathrm{~kg} / \mathrm{m}^{2}$ 以上の患者は SSI 発生率が高い傾向に あった。平均 BMI が $23 \pm 3.6 \mathrm{~kg} / \mathrm{m}^{2}$ であり, 肥満患者が 少なかったことから多変量解析の補正因子からは除外した が, 肥満患者に対しては十分に注意する必要がある. 開胸 術の既往がある患者は縦隔癒着により手術時間が延長し污 染のリスクにつながることが報告され20), 本研究でも開胸 歴のある患者は, SSI 発生率が高い傾向にあった。

以上, 先行研究で報告されているリスク因子が今回の検 討で有意差を示せなかったことは, サンプル数の少なさに 起因しているかもしれない。また後ろ向きの観察研究であ り, 単一施設の結果に基づくものであるため, 異なる施設 に扔いては患者背景や手術因子の違いにより結果が变わる 可能性がある. 加えて執刀前抗菌薬投与時間に扎いて, 投 与終了時間の調査はできていないこと, 手術室では抗菌薬 投与終了時間の記載をルール化していないことから, 投与 終了時間の把握ができないことは, 本研究の限界である. 抗菌薬は執刀時には投与を完了しておくことが推奨されて おり，今後は，投与完了時刻を記録に残し，評価すること が課題である.

今回の研究で, 新病院移転後もSSI 対策がなされていた が，一方でバンドル実施率の低い対策も明確になった。心 臓外科手術は過大な侵襲を伴う医療行為であり, 高齢者へ の手術や手術手技の高度化により, ハイリスクな患者が増 加している．継続したモニタリングと評価はSSI 対策にお いてきわめて重要と考える. 今回明らかになったリスク因 子と, サブ解析による更なる検討を深めることで, より精 度の高いSSI 対策を構築し, 継続していくことが肝要であ る.

\section{結 論}

本研究により, 開心術に扎ける SSI の発生する危険性が 高い要因は複合手術であり, バンドル実施率が向上した手 術時期と, 切開の 1 時間前以内に予防抗菌薬の投与開始は
SSI の発生する危険性が低いことが分かった. SSI 予防と しては, バンドルの遵守と継続したモニタリング, 予防抗 菌薬は切開の 1 時間前以内に投与する意義が示唆された。

謝辞 : 本論文作成にあたり, 感染対策についてご指導い ただいた神戸市立医療センター中央市民病院感染管理室の 土井朝子先生に深く感謝申し上げます。

\section{文献}

1) de Lissovoy G, Fraeman K, Hutchins $V$ et al. Surgical site infection : incidence and impact on hospital utilization and treatment costs. Am J Infect Control $2009 ; 37$ : 387-97.

2) Japan Nosocomial Infection Surveillance Kokaijoho 2016 nen 1 gatsu $\sim 12$ gatsu. http://www.nih-janis.jp/report/ssi.html (Accessed 1 June 2018)

3) Goh SSC. Post-sternotomy mediastinitis in the modern era. J Card Surg $2017 ; 32: 556-66$.

4) Lemaignen A, Birgand G, Ghodhbane $W$ et al. Sternal wound infection after cardiac surgery : incidence and risk factors according to clinical presentation. Clin Microbiol Infect $2015 ; 21: 674 . e 11-8$.

5) Martin ET, Kaye KS, Knott $C$ et al. Diabetes and risk of surgical site infection:a systematic review and metaanalysis. Infect Control Hosp Epidemiol 2016 ; 37 : 88-99.

6) Fry DE. Surgical site infections and the surgical care improvement project (SCIP) : evolution of national quality measures. Surg Infect (Larchmt). $2008 ; 9: 579-84$.

7) Munday GS, Deveaux $P$, Roberts $H$ et al. Impact of implementation of the Surgical Care Improvement Project and future strategies for improving quality in surgery. Am J Surg $2014 ; 208: 835-40$.

8) Mangram AJ, Horan TC, Pearson ML et al. Guideline for prevention of surgical site infection, 1999. Hospital infection Control Practices Advisory Committee. Infect Control Hosp Epidemiol 1999; $20: 250-80$.

9) Shinkai N, Shomura Y, Okada Y et al. The risk factors of surgical site infection after valvular heart surgery. Jpn J Cardiovasc Surg 2013; 42: 108-13.

10) Baillot $R$, Cloutier $D$, Montalin L et al. Impact of deep sternal wound infection management with vacuum-assisted closure therapy followed by sternal osteosynthesis : a 15-year review of 23,499 sternotomies. Eur J Cardiothorac Surg 2010; 37 : 880-7.

11) Bratzler DW, Dellinger EP, Olsen KM et al. Clinical practice guidelines for antimicrobial prophylaxis in surgery. Am J Health Syst Pharm $2013 ; 70$ : 195-283.

12) Institute for Healthcare Improvement. Evidence-Based Care Bundles. http://www.ihi.org/Topics/Bundles/Pages/de fault.aspx (Accessed 1 June 2018)

13) How-to guide : prevent surgical site infections. Cambridge (MA) : Institute for Healthcare Improvement, 2012. http:// www.ihi.org/Topics/SSI/Pages/default.aspx (Accessed 1 June 2018)

14) High impact intervention: care bundle to prevent surgical site infection. London : Department of Health, 2011. http:// webarchive.nationalarchives.gov.uk/20120118171639/ http://hcai.dh.gov.uk/files/2011/03/2011-03-14-HII-PreventSurgical-Site-infection-FINAL.pdf (Accessed 1 June 2018)

15) Shomura Y, Okada $Y$, Shinkai $N$ et al. Preventing surgical site infection in cardiovascular surgery: cooperation be- 
tween the Infection Control Team and Surgeons. J Cardiovasc Surg $2013 ; 42: 377-83$.

16) Kramer R, Groom R, Weldner D et al. Glycemic control and reduction of deep sternal wound infection rates. Arch Surg $2008 ; 143: 451-6$.

17) Centers for Disease Control and Prevention Guideline for the Prevention of Surgical Site Infection, 2017. https://jamanet work.com/journals/jamasurgery/fullarticle/2623725 (Accessed 1 June 2018)

18) Global Guidelines for the Prevention of Surgical Site
Infection, 2016. http://apps.who.int/iris/bitstream/10665/ 250680/1/9789241549882-eng.pdf ? ua=1 (Accessed 1 June 2018)

19) Yano M, Tanaka K, Motoori M et al. Surgical techniques for obese patients to avoid post-operative complications. Surg Ther 2007 ; $96: 249-53$.

20) Milano CA, Kesler K, Archibald N et al. Mediastinitis after coronary artery bypass graft surgery. Risk factors and longterm survival. Circulation 1995 ; 92 : 2245-51. 